\title{
Introduction of a rapid, simple radioimmunoassay and quality control scheme for thyroxine
}

\author{
LYNN NYE, 1 MITHAL HASSAN, EILEEN WILLMOTT, AND J. LANDON \\ From the Department of Chemical Pathology, St Bartholomew's Hospital, London EC1
}

SYNOPSIS A simple radioimmunoassay has been developed for service purposes to determineo serum total thyroxine levels. Only three additions are required, of standard or sample, labelled: thyroxine and antibody in polyethylene glycol. After 2 hours' incubation at room temperature the antibody-bound and free fractions are separated by centrifugation. Serum total thyroxine levels were measured in 195 euthyroid subjects and it was established that normal values lay within theo range 57 to $155 \mathrm{nmol} / \mathrm{l}$. Serial blood samples taken over a 24-hour period, from 11 subjects, indicated. that there was no circadian rhythm so that samples for total thyroxine assay can be taken at any time of the day. Similar results were obtained using serum or plasma. Satisfactory results were obtained for three quality control sera when measured by seven different laboratories using thise method.

Until recently the determination of protein-bound iodine (PBI) was the single most widely used in-vitro test for the evaluation of thyroid function; however, its diagnostic accuracy is severely impaired because many samples are contaminated by iodine. Murphy and Pattee (1964) developed a protein-binding assay for thyroxine $\left(\mathrm{T}_{4}\right)$ which was unaffected by either endogenous or exogenous iodine. Because of difficulties in raising suitable antibodies, the development of more specific radioimmunoassays was slow. In 1971, Chopra and his colleagues succeeded in raising antibodies to $T_{4}$ by immunizing rabbits with thyroglobulin, and since then other workers have produced more specific antibodies with higher titres by immunizing rabbits and sheep with $\mathbf{T}_{4}$ :serum albumin conjugates (Mitsuma et al, 1972; Corcoran et al, 1973).

Several radioimmunoassays for $\mathrm{T}_{4}$ have now been developed employing a variety of compounds to block endogenous thyroxine-binding globulin (of which the most common are 8-anilino 1-naphthalene sulphonic acid and merthiolate), barbital buffer to block binding to endogenous pre-albumin, and several different techniques to separate the antibodybound and free fractions. A comparison of polyethylene glycol (PEG), charcoal, antibody bound to

${ }^{1}$ Reprint requests to $\mathrm{LN}$.

Received for publication 29 October 1975 solid phase supports, and ion exchange resing (Ratcliffe et al, 1974a) showed that PEG gave the lowest 'between batch' coefficient of variation, was inexpensive (cost per tube $0.03 \mathrm{p}$ ), and, unlike. charcoal, could be added at the beginning of the assay and was not time dependent.

The present paper summarizes our experience with a service radioimmunoassay for $T_{4}$ based om the use of PEG for separation and phosphate ratherthan barbital buffer, as the former was employed. for the other service assays. The results of a quality? control scheme involving seven different laboratories which employ the same reagents and assay protocob are also reported.

\section{Material and Methods}

BUFFERS

$0.05 \mathrm{M}$ phosphate, $\mathrm{pH} 7.4$

$0.05 \mathrm{M}$ barbital, pH 8.6

T4 FREE SERUM

$T_{4}$ was extracted by the addition of $10 \mathrm{~g}$ of dry unwashed Norit OL charcoal (Hopkins and Williams) to $100 \mathrm{ml}$ of pooled serum and mixing overnight by vertical rotation at room temperature. The charcoa $\vec{D}$ and adsorbed $T_{4}$ were removed by centrifugation and filtration through millipore filters. The addition? of a trace amount of ${ }^{125} \mathrm{I}_{-} \mathrm{T}_{4}$ showed that $98-100 \%$ was removed. 


\section{STANDARD SOLUTIONS}

$T_{4}$, in the free acid form (obtained from Sigma), was dissolved in $0.02 \mathrm{M} \mathrm{NaOH}$ and diluted in $\mathrm{T}_{4}$ free serum to give solutions containing 10 to 400 nmol/l.

ANS $/{ }^{125}$ I $_{-T} \mathrm{~T}_{4}$

ANS (obtained from Sigma) was dissolved in buffer to give a solution containing $8 \mathrm{mg} / \mathrm{ml}$, to which was added 125I-T 4 (obtained from the Radiochemical Centre, Amersham) at a concentration of $10 \mathrm{ng} / \mathrm{ml}$.

POLYETHYLENE GLYCOL 6000 (PEG)

PEG (obtained from British Drug Houses) was dissolved in buffer to give a solution containing $200 \mathrm{~g} / \mathrm{l}$.

ANTI-T 4 SERUM

An antiserum was raised by Dr T. G. Merrett* in a sheep by immunization with a $\mathrm{T}_{4}$ :BSA conjugate, which cross-reacted with triiodothyronine only to the extent of $1.3 \%$.

\section{ANTI-T 4/PEG}

Antiserum was added to $20 \%$ PEG during vigorous mixing on a magnetic stirrer and was allowed to mix for a further 10 minutes before addition to the incubation tubes. This ensured an even suspension.

THYROXINE RADIOIMMUNOASSAY (T4 RIA) Reagents were added to LP3 tubes in the order and volumes summarized below:

$\begin{array}{ll}\text { Serum or standard } \mathrm{T}_{4} & 100 \mu \mathrm{l} \\ { }_{125} \mathrm{I}-\mathrm{T}_{4} / \mathrm{ANS} & 100 \mu \mathrm{l} \\ (1 \mathrm{ng})(800 \mu \mathrm{g}) & \end{array}$

Anti-T 4 serum in $20 \%$ PEG $500 \mu$ l (to give a final antiserum dilution of $1: 2500$ )

In addition three sets of tubes were prepared to measure:

(a) the maximum binding of ${ }^{125} \mathrm{I}_{-} \mathrm{T}_{4}\left(\mathrm{~B}_{0}\right)$ in which unlabelled $\mathrm{T}_{4}$ was replaced by $\mathrm{T}_{4}$ free serum;

(b) the blank $\left(B_{b}\right)$ in which unlabelled $T_{4}$ was replaced by $\mathrm{T}_{4}$ free serum and the antibody/PEG solution by $20 \% \mathrm{PEG}$, and

(c) the total radioactivity (T) in which ${ }^{125} \mathrm{I}-\mathrm{T}_{4}$ only was added. The tubes were vortexed and incubated at room temperature for 2 hours. Antibody-bound and free fractions were separated by centrifugation for 15 minutes at $700 \mathrm{~g}$ and aspiration of the supernatant fluid. The precipitates, which contained the bound fraction, were counted in an automatic gamma counter.

In this laboratory, standards and serum samples were dispensed with an Ependorf pipette, ANS/

* Rast Allergy Unit, Benenden Chest Hospital, Benenden Kent.
${ }^{125} \mathrm{I}_{-} \mathrm{T}_{4}$ using a Hamilton syringe, and antibody/PEG with a repeating syringe.

\section{CALCULATIONS}

After subtraction of the blank, the antibody-bound fraction $\left(B_{i}\right)$ was expressed either as a percentage of the total radioactivity $\left(B_{1}-B_{b} / T \times 100\right)$ or as a percentage of the maximum binding $\left(B_{1}-B_{b} / B_{0}\right.$ $\times 100$ ). The best cubic curve was computed for the standards using the method of least squares, and the amount of $T_{4}$ in the test samples was interpolated automatically using a suitable computer program and a 9100b calculator (Hewlett-Packard).

Manual methods of calculation, although more time consuming, could be employed which gave results identical with those obtained by computerized techniques.

INVESTIGATION OF EFFECT OF BARBITAL BUFFER ON PRE-ALBUMIN BINDING

A standard curve, 10 samples, and the three quality control sera were measured in duplicate $(a)$ in barbital buffer, pH 8.6 and $(b)$ in phosphate buffer, $\mathrm{pH} 7 \cdot 4$.

\section{QUALITY CONTROL SCHEME}

Control sera: A pool of normal serum (the normal quality control, NQC) was prepared, and its $T_{4}$ content was determined repeatedly and found to be approximately $100 \mathrm{nmol} / \mathrm{l}$. An aliquot of this serum was diluted 1:2 with $T_{4}$ free serum to give the low quality control serum (LQC) containing approximately $50 \mathrm{nmol} / \mathrm{l}$, and standard $\mathrm{T}_{4}$ was added to another aliquot to give the high quality control serum (HQC) containing approximately $200 \mathrm{nmol} / \mathrm{l}$. These three pools were aliquoted and stored at $-20^{\circ} \mathrm{C}$.

To assess intralaboratory variation the "withinbatch' coefficient of variation was assessed by 10 simultaneous analyses of each of the quality control sera, and the 'between-batch' by analysis of the NQC in duplicate in 61 consecutive assays.

To assess interlaboratory variation the three quality control sera were sent by post to six different laboratories where the $T_{4}$ content was determined using the same reagents and a protocol identical with that described in this paper.

\section{COLLECTION OF BLOOD SAMPLES}

(a) Blood samples were collected from 109 healthy laboratory personnel, aged 16 to 45 years, comprising 61 men and 48 women of whom 18 were taking oral contraceptives. An additional series of samples from 86 clinically euthyroid subjects was kindly supplied by Professor R. Hall. These subjects, comprising 39 men and 46 women 
aged 18 to 87 years, all showed a normal thyrotrophin (TSH) response to the thyrotrophin releasing hormone (TRH) test (Ormston et al, 1971), indicating that they were also 'biochemically euthyroid'.

(b) To assess any circadian changes, six men and five women, aged 21 to 34 years, had repeated venepunctures at 2-hourly intervals between 8 am and $8 \mathrm{pm}$, and also at midnight and at $4 \mathrm{am}$.

(c) To compare serum and plasma, blood samples were collected from 10 clinically euthyroid subjects, half of each sample being collected into a plain glass tube and allowed to clot, while the remainder was collected into a lithium heparinized tube (containing approximately $10 \mathrm{U}$ heparin $/ \mathrm{ml}$ ).

All samples, unless otherwise stated, were serum stored at $-20^{\circ} \mathrm{C}$ before assay.

\section{Results}

A typical standard curve is shown in figure 1. Blank values were approximately $10 \%$. The 'within-batch' coefficient of variation for the low, normal, and high quality control sera were $5.6,2.5$, and $6.2 \%$ respectively, and the 'between-batch' coefficient of variation for the normal quality control serum was $5.5 \%$. Table I shows the values for the three quality control sera when measured by six different laboratories using this method and these were considered satisfactory.

Doubling dilutions of six serum samples were prepared using $T_{4}$ free serum and their $T_{4}$ content was measured. Figure 1 shows parallelism with the standard curve.

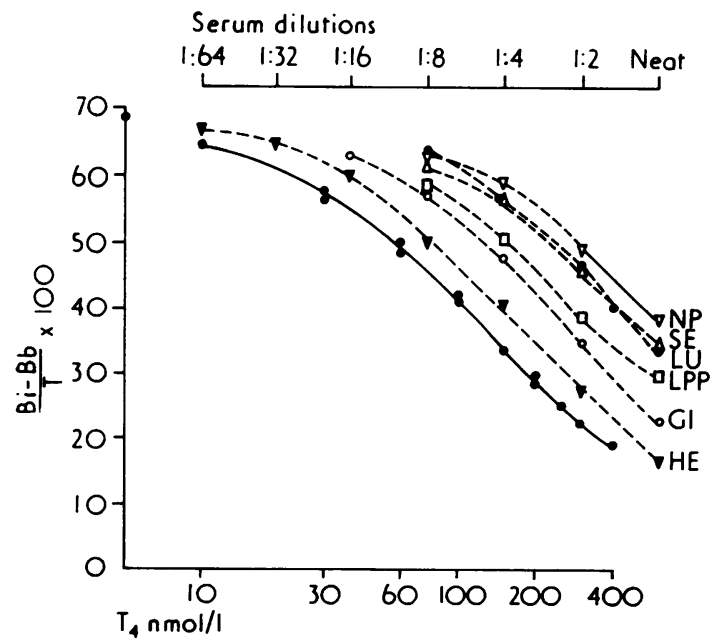

Fig 1 Parallel inhibition of the binding of ${ }^{125} I-T_{4}$ exhibited by serial dilutions of serum samples (-....-.) compared with standard solutions (-

\begin{tabular}{|c|c|c|c|c|}
\hline \multirow[t]{2}{*}{ Hospital } & \multicolumn{3}{|c|}{$T_{4}$ in mmol/l } & \multirow{2}{*}{$\begin{array}{l}\text { Between-assay }{ }^{1} \\
\text { Coefficient of } \\
\text { Variation }\end{array}$} \\
\hline & $L Q C$ & $N Q C$ & $H Q C$ & \\
\hline SBH & 50 & 99 & 197 & 5.5 \\
\hline 1 & 48 & 92 & 180 & $5 \cdot 5$ \\
\hline 2 & 71 & 114 & 219 & 7.9 \\
\hline 3 & 48 & 102 & 199 & $5 \cdot 4$ \\
\hline 4 & 43 & 103 & 194 & - \\
\hline 5 & 46 & 90 & 170 & $4 \cdot 6$ \\
\hline & 39 & 90 & 180 & 2.9 \\
\hline Mean & 49 & 100 & 191 & \\
\hline SD & $10 \cdot 2$ & $8 \cdot 7$ & 16.9 & \\
\hline CV & $20 \cdot 8$ & $8 \cdot 7$ & $8 \cdot 7$ & \\
\hline
\end{tabular}

${ }^{1}$ These figures were obtained for serum with $T_{4}$ values which werê within the normal range. The number of determinations varied between 6 and 61 .

SBH $=$ St. Bartholomew's Hospital

Figure 2 shows standard curves obtained with bar=

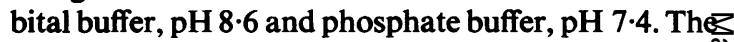
difference in binding was probably due to $\mathrm{pH}$ effects on the antigen:antibody reaction as demonstratedo in a triiodothyronine RIA (Hüfner and Hesch. 1973) where higher binding was obtained at $\mathrm{pH} 7.4$ than at 8.6. The total $T_{4}$ values for the 10 serund samples and three quality control sera were similas when measured in both buffer systems (table II) indicating that in the presence of a high aviditio antiserum to $T_{4}$ the effect of pre-albumin binding on results is insignificant.

Results for 177 normal euthyroid subjects and $18^{8}$ females taking oral contraceptives are shown in figure 3. Excluding the latter, there was no sex. difference, the mean serum total $\mathbf{T}_{4}$ for womes being $107 \pm 21$ and for men $103 \pm 17 \mathrm{nmol} / \mathrm{l}$. Totas $\mathrm{T}_{4}$ levels did not decrease with age, thus the meaญ.

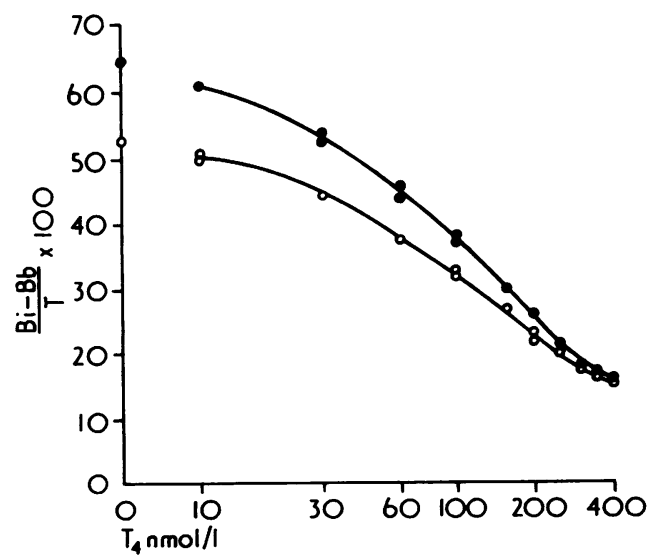

Fig 2 Comparison of standard curves in phosphate buffex (O) and barbital buffer (O). 


\begin{tabular}{|c|c|c|}
\hline \multirow[t]{2}{*}{ Sample } & \multicolumn{2}{|l|}{ Buffer } \\
\hline & $\begin{array}{r}\text { Phosphate, } p H 7 \cdot 4 \\
T, \text { in }\end{array}$ & $\begin{array}{l}\text { Barbital,pH 8.6 } \\
\text { mmol/l }\end{array}$ \\
\hline 1 & 45 & 42 \\
\hline 2 & 55 & 50 \\
\hline 3 & 72 & 74 \\
\hline 4 & 76 & 74 \\
\hline 5 & 86 & 99 \\
\hline 6 & 105 & 112 \\
\hline 7 & 107 & 104 \\
\hline 8 & 118 & 119 \\
\hline 9 & 150 & 156 \\
\hline 10 & 153 & 157 \\
\hline LQC & 48 & 50 \\
\hline NQC & 102 & 103 \\
\hline HQC & 185 & 199 \\
\hline Mean & $100 \cdot 1$ & 103.0 \\
\hline SD & \pm 43.1 & \pm 46.8 \\
\hline
\end{tabular}

Table II Serum $T_{4}$ levels measured in phosphate and barbital buffer

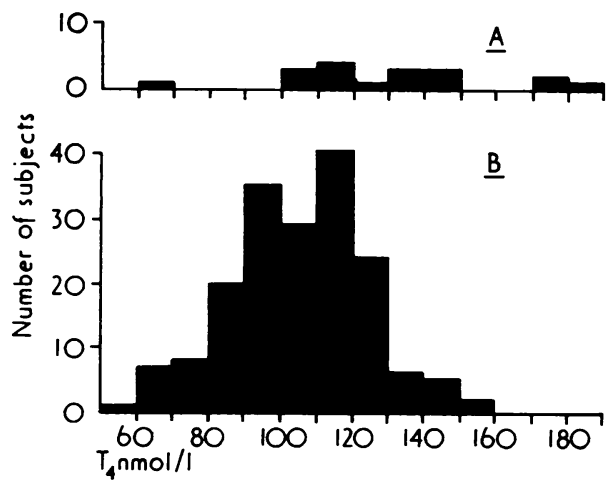

Fig 3 Distribution of $T_{4}$ levels $(A)$ in 18 female subjects taking oral contraceptives and $(B)$ in 177 normal euthyroid subjects.

values for 140 subjects aged 16 to 59 years was 105 \pm 19 and for 37 aged 60 to 87 was $103 \pm 16 \mathrm{nmol} / 1$. The mean for the total normal population was 105 \pm 19. Although the mean serum total $T_{4}$ for the subjects taking oral contraceptives was significantly higher $(130 \pm 30 \mathrm{nmol} / \mathrm{l} ; \mathrm{P}<0.001)$, only three had levels which were outside the normal range of 57 to $155 \mathrm{nmol} / \mathrm{l}$.

The results of the circadian rhythm study are shown in table III. Although the coefficients of variation for individuals were slightly higher than that of the method, no definite pattern was observed.

Similar results were obtained for serum and lithium heparinized plasma, the mean total $\mathrm{T}_{4}$ levels for the 10 subjects studied being $94.7 \pm 13.9$ and $94.2 \pm$ $14.4 \mathrm{nmol} / \mathrm{l}$ respectively.

\section{Discussion}

Thyroid disorders are among the commonest endocrine abnormalities, and, therefore, most chemical pathology laboratories receive large numbers of requests which necessitate a simple screening procedure in order to cope with the ever increasing demand.

Until recently, total $T_{4}$ levels were determined either indirectly as PBI or more directly by proteinbinding methods. The results obtained, however, may be affected by non-specific interference. In an investigation of thyroid disease in geriatric subjects, Jefferys (1972) showed that at least one patient in 10 had a spuriously raised PBI attributable to iodine contamination while, in a study of the stability of thyroid hormones (Nye et al, 1975), it was shown that when plasma and serum samples are stored at room temperature their apparent $T_{4}$ content increases significantly when measured by proteinbinding methods but remains stable for at least two weeks when measured by radioimmunoassay. Rootweld (1975) has demonstrated that this apparent increase in total $\mathbf{T}_{4}$ is due to non-specific interference by free fatty acids which are released slowly on storage. This instability problem is obviously important when samples are sent by post. Thus radioimmunoassay is the only specific method which is available for the measurement of total $T_{4}$.

Radioimmunoassays for $T_{4}$ are also simpler and

\begin{tabular}{|c|c|c|c|c|c|c|c|c|c|c|c|c|c|c|}
\hline \multirow[t]{2}{*}{ Subject } & \multirow[t]{2}{*}{ Age } & \multirow[t]{2}{*}{$\operatorname{Sex}$} & \multicolumn{9}{|c|}{ Time throughout Day } & \multirow[t]{2}{*}{ Mean } & \multirow[t]{2}{*}{$S D$} & \multirow[t]{2}{*}{$\mathrm{CV} \%$} \\
\hline & & & 08.00 & 10.00 & 12.00 & 14.00 & 16.00 & 18.00 & 20.00 & 00.00 & 04.00 & & & \\
\hline $\begin{array}{l}\text { RW } \\
\text { ADH } \\
\text { JK } \\
\text { VC } \\
\text { JD } \\
\text { CB } \\
\text { JG } \\
\text { EN } \\
\text { SD } \\
\text { AET } \\
\text { HL }\end{array}$ & $\begin{array}{l}34 \\
22 \\
30 \\
25 \\
23 \\
26 \\
26 \\
21 \\
21 \\
21 \\
25\end{array}$ & $\begin{array}{l}\mathbf{M} \\
\mathbf{M} \\
\mathbf{M} \\
\mathbf{F} \\
\mathbf{F} \\
\mathbf{F} \\
\mathbf{F} \\
\mathbf{M} \\
\mathbf{F} \\
\mathbf{M} \\
\mathbf{M}\end{array}$ & $\begin{array}{l}\overline{130} \\
\overline{155} \\
131 \\
84 \\
111 \\
\overline{100} \\
103 \\
69\end{array}$ & $\begin{array}{c}112 \\
93 \\
165 \\
150 \\
95 \\
112 \\
102 \\
114 \\
84\end{array}$ & $\begin{array}{r}84 \\
123 \\
103 \\
164 \\
145 \\
104 \\
116 \\
109 \\
111 \\
61 \\
-\end{array}$ & $\begin{array}{r}105 \\
105 \\
104 \\
127 \\
140 \\
92 \\
90 \\
109 \\
118 \\
80 \\
73\end{array}$ & $\begin{array}{r}95 \\
109 \\
106 \\
147 \\
129 \\
84 \\
97 \\
106 \\
107 \\
69 \\
77\end{array}$ & $\begin{array}{r}92 \\
118 \\
101 \\
159 \\
138 \\
89 \\
85 \\
101 \\
119 \\
68 \\
99\end{array}$ & $\begin{array}{r}95 \\
116 \\
98 \\
157 \\
97 \\
88 \\
94 \\
121 \\
109 \\
77 \\
68\end{array}$ & $\begin{array}{r}98 \\
124 \\
97 \\
134 \\
97 \\
100 \\
84 \\
110 \\
108 \\
72 \\
62\end{array}$ & $\begin{array}{r}95 \\
125 \\
93 \\
131 \\
- \\
90 \\
90 \\
115 \\
89 \\
92 \\
58\end{array}$ & $\begin{array}{r}97 \\
119 \\
99 \\
148 \\
128 \\
92 \\
98 \\
109 \\
108 \\
77 \\
74\end{array}$ & $\begin{array}{r}8 \cdot 4 \\
8 \cdot 5 \\
4 \cdot 9 \\
14 \cdot 6 \\
20 \cdot 5 \\
6 \cdot 8 \\
12 \cdot 2 \\
6 \cdot 6 \\
9 \cdot 3 \\
14 \cdot 3 \\
13\end{array}$ & $\begin{array}{r}8 \cdot 7 \\
7 \cdot 1 \\
5 \cdot 0 \\
9 \cdot 9 \\
16 \cdot 0 \\
7 \cdot 4 \\
12 \cdot 5 \\
6 \cdot 0 \\
8 \cdot 6 \\
18 \cdot 6 \\
17 \cdot 7\end{array}$ \\
\hline
\end{tabular}

Table III $T_{4}$ levels measured by RIA in the circadian rhythm study 
quicker to perform than protein-binding techniques which require extraction of $T_{4}$ from endogenous binding proteins before assay. In addition, they are much less expensive than commercially available $\mathrm{T}_{4}$ kits, based on protein-binding methods. Preparation and distribution costs of anti- $\mathrm{T}_{4}$ serum are negligible; the sheep employed in this study was bought and maintained for approximately $£ 15$ per month, and the antiserum was despatched to other laboratories by post in an unfrozen state. With regular immunization and bleeding procedures one animal will produce enough antiserum to supply an entire region for several years. Thus, considering reagents alone, for a commonly employed binding kit, the cost per tube is at least 100 times greater than for the RIA described here (table IV).

The normal values obtained in this study compare closely with those of other workers employing protein binding or radioimmunoassays (table V). It has been in routine use in this laboratory for a year and is currently employed in at least 10 other hospitals, of which six took part in a joint quality control scheme. Both 'within' and 'between' laboratory coefficients of variation were less than $9 \%$

\begin{tabular}{|c|c|c|c|}
\hline \multicolumn{2}{|l|}{$R I A$} & \multicolumn{2}{|l|}{ Kit } \\
\hline Reagent & $\begin{array}{l}\text { Cost/100 tubes } \\
£\end{array}$ & Reagent & $\begin{array}{l}\text { Cost/100tubes } \\
£\end{array}$ \\
\hline $\begin{array}{l}\text { Buffer } \\
125 I-T_{4}\end{array}$ & $\begin{array}{l}0.006 \\
0.525\end{array}$ & $\begin{array}{l}\text { Kit reagents } \\
\text { Ethanol }\end{array}$ & $\begin{array}{r}63 \cdot 6 \\
0 \cdot 1\end{array}$ \\
\hline $\begin{array}{l}\text { ANS } \\
\text { PEG } 6000\end{array}$ & $\begin{array}{l}0.001 \\
0.023\end{array}$ & & \\
\hline \multicolumn{2}{|c|}{$\begin{array}{l}\text { Total reagent cost } / 100 \text { tubes } \\
\text { £0.555 }\end{array}$} & \multicolumn{2}{|c|}{$\begin{array}{l}\text { Total reagent cost } / 100 \text { tubes } \\
£ 63.7\end{array}$} \\
\hline
\end{tabular}

Table IV Comparison between the reagent costs of the $T_{4} R I A$ and a commonly used protein-binding kit

\begin{tabular}{|c|c|c|c|c|c|}
\hline \multicolumn{3}{|c|}{ Protein-binding Assay } & \multicolumn{3}{|c|}{ Radioimmunoassay } \\
\hline Author & $\begin{array}{l}\text { Mean } \pm \\
\text { SD }\end{array}$ & Range & Author & $\begin{array}{l}\text { Mean } \pm \\
S D\end{array}$ & Range \\
\hline $\begin{array}{l}\text { Murphy and } \\
\text { Pattee (1964) }\end{array}$ & $130=26$ & - & Chopra (1972) & $107 \div 31$ & - \\
\hline $\begin{array}{l}\text { Ekins et al } \\
\text { (1969) }\end{array}$ & - & $58-148$ & $\begin{array}{l}\text { Mitsuma et al } \\
\text { (1972) }\end{array}$ & $95 \pm 25$ & $50-126$ \\
\hline $\begin{array}{l}\text { Braverman } \\
\text { et al (1971) }\end{array}$ & $95 \pm 19$ & - & $\begin{array}{l}\text { Beckers et al } \\
\text { (1973) }\end{array}$ & $122 \pm 25$ & - \\
\hline \multirow[t]{5}{*}{$\begin{array}{l}\text { Alexander and } \\
\text { Jennings (1974 }\end{array}$} & & $58-154$ & $\begin{array}{l}\text { Ratcliffe et al } \\
\text { (1974b) }\end{array}$ & $99 \pm 21$ & $55-144$ \\
\hline & & & $\begin{array}{l}\text { Meinhold and } \\
\text { Wenzel (1974) }\end{array}$ & $103 \pm 21$ & $71-151$ \\
\hline & & & $\begin{array}{l}\text { Black et al } \\
(1974)\end{array}$ & 120 & $75-172$ \\
\hline & & & $\begin{array}{l}\text { Marsden et al } \\
\text { (1975) }\end{array}$ & $81 \pm 14$ & - \\
\hline & & & Present study & $103 \pm 21$ & $57-155$ \\
\hline
\end{tabular}

Table $\mathrm{V}$ Normal $T_{4}$ levels as reported in the literature (converted to nmol/l) except for the low quality control serum in which discrepant results of $71 \mathrm{nmol} / 1$ and $39 \mathrm{nmol} / \mathrm{L}$ obtained from two different hospitals increased the 'between' laboratory coefficient of variation too $20.8 \%$. A regular exchange of standard material and흐 control sera is in progress and it is hoped thate 'between' laboratory variation will improve with $\vec{Q}$ time.

The preparation of reagents is simple, although ${ }^{\infty}$ the extraction of $T_{4}$ from serum is a time-consuming $\vec{\circ}$ process. Fortunately, large batches can be prepared $\overrightarrow{ }$ at one time and are stable for at least six monthso when stored at $-20^{\circ} \mathrm{C}$. Marsden et al (1975) described a $T_{4}$ RIA in which $T_{4}$ free serum was not required provided that serum samples were diluted: between 1:10 and 1:100 with buffer. This predilution step is, however, also time-consuming, especially when large numbers of samples are being processed.을

The assay may be operated either manually in the small laboratory or adapted for use with semi-z automated equipment (such as the Compupet and Micromedic pipetting systems) when larger batches $\overrightarrow{0}$ of samples are assayed. Both lithium heparinized plasma and serum samples are suitable. No circadian. rhythm was observed, and blood samples mayo therefore be collected at any time.

In most cases of suspected thyroid dysfunction $a$ diagnosis can be substantiated by the estimation of total serum $\mathrm{T}_{4}$ levels together with a simple thyroid $\mathbb{Q}$ hormone uptake test, such as the Thyopac 3 kitö (Radiochemical Centre), which gives a measure of 3 available binding sites on circulating TBG. The? Thyopac 3 assay and the $T_{4}$ radioimmunoassay? reported here can easily be carried out within a응 working day and constitute a satisfactory screening: technique. In most cases no further tests need be 3 . done.

\section{References}

Alexander, N. M. and Jennings, J. F. (1974). Analysis of total serum thyroxine by equilibrium competitive protein binding on small, re-usable Sephadex columns. Clin. Chem., 20, 553-559.

Beckers, C., Cornette, C., and Thalasso, M. (1973). Evalua- o tion of serum thyroxine by radioimmunoassay. $J$. nucl.N Med., 14, 317-320.

Black, E. G., Griffiths, R. S., Wall, D. W., Finucane, J., and Hoffenberg, R. (1974). The radioimmunoassay of tri-O iodothyronine $\left(\mathrm{T}_{3}\right)$ and thyroxine $\left(\mathrm{T}_{4}\right)$. Internationalo Conference on Thyroid Hormone Metabolism, Glasgow, $\frac{\mathrm{C}}{\mathrm{D}}$ Scotland, 1974.

Braverman, L. E., Vagenakis, A. G., Foster, A. E., and ${ }^{+}$ Ingbar, S. H. (1971). Evaluation of a simplified technique ${ }^{-}$ for the specific measurement of serum thyroxine concen-O tration. J. clin. Endocr., 32, 497-502.

Chopra, I. J. (1972). A radioimmunoassay for measurement of thyroxine in unextracted serum. J. clin. Endocr., 34, 938-947.

Chopra, I. J., Nelson, J. C., Solomon, D. H., and Beall, G. N. (1971). Production of antibodies specifically binding tri-ฮ̊ 
iodothyronine and thyroxine. J. clin. Endocr., 32, 299-308.

Corcoran, J. M., Eastman, C. J., Ekins, R. P., and Paul, W. (1973). The production of antisera for the radioimmunoassay of thyroxine. (Abstr.) J. Endocr., 58, xxii.

Ekins, R. P., Williams, E. S., and Ellis, S. (1969). The sensitive and precise measurement of serum thyroxine by saturation analysis (competitive protein binding assay). Clin. Biochem., 2, 252-288.

Hüfner, M. and Hesch, R. D. (1973). Radioimmunoassay for triiodothyronine in human serum. Acta endocr. (Kbh.), 72, 464-474.

Jefferys, P. M. (1972). The prevalence of thyroid disease in patients admitted to a geriatric department. Age and Ageing, 1, 33-37.

Marsden, P., Facer, P., Acosta, M., and Howorth, P. J. N. (1975). A comparative study of serum total thyroxine estimation on unextracted serum by radioimmunoassay and by competitive protein binding. J. clin. Path., 28, 608-612.

Meinhold, H. and Wenzel, K. W. (1974). Radioimmunoassay of thyroxine in unextracted serum. Horm. metab. Res., 6, 169-170.

Mitsuma, T., Colucci, J., Shenkman, L., and Hollander, C. S. (1972). Rapid simultaneous radioimmunoassay for triiodothyronine and thyroxine in unextracted serum. Biochem. biophys. Res. Commun., 46, 2107-2113.

Murphy, B. E. P. and Pattee, C. J. (1964). Determination of thyroxine utilizing the property of protein-binding. J. clin. Endocr., 24, 187-196.

Nye, L., Yeo, T. H., Chan, V., Goldie, D., and Landon, J. (1975). Stability of thyroxine and triiodothyronine in biological fluids. J. clin. Path., 28, 915-919.

Ormston, B. J., Cryer, R. J., Garry, R., Besser, G. M., and Hall, R. (1971). Thyrotrophin-releasing hormone as a thyroid-function test. Lancet, July 3, 10-14.

Ratcliffe, W. A., Challand, G. S., and Ratcliffe, J. G. (1974a). A critical evaluation of separation methods in radioimmunoassays for total triiodothyronine and thyroxine in unextracted human serum. Ann. clin. Biochem., 11, 224-229.

Ratcliffe, W. A., Ratcliffe, J. G., McBride, A. D., Harland, W. A., and Randall, T. W. (1974b). The radioimmunoassay of thyroxine in unextracted human serum. Clin. Endocr. 3, 481-488.

Rootweld, K. (1975). Specificity of competitive proteinbinding radioassay of serum thyroxine determination. In The 7th International Thyroid Conference, Boston, U.S.A. (International Congress Series 361), p. 8. Excerpta Medica, Amsterdam. 